BRITAIN

\section{Genetic manipulation: guidelines out}

Eleanor Lawrence studies the report on genetic manipulation experiments and the consultative document on regulations to control them.

GeNETIC manipulation experiments involving artificially prepared recombinant DNA elements are to go ahead in the United Kingdom under certain specified conditions. Those intending to do such experiments must notify the Health and Safety Commission (HSC), an arm of the Department of Employment, and will also notify an independent Genetic Manipulation Advisory Group (GMAG) which will advise them of the conditions of containment required. The HSC is seeking powers to enforce the conditions recommended by the GMAG, and has put forward a set of draft regulations.

The voluntary code of practice and the proposed establishment of a national Genetic Manipulation Advisory Group are the main recommendations of the long-awaited report of the Williams Working Party on the Practice of Genetic Manipulation, published last week with government approval*. The aim of the technical guidelines and the machinery to put them into practice is to protect workers and the general public from the possible hazards presented by bacteria into which foreign genes have been transplanted by novel techniques developed several years ago in the United States.

These techniques enable DNA from another source (be it human, animal, plant, virus or an unrelated bacterium) to be spliced on to DNA from a phage or plasmid vector and introduced into a bacterium. The fear is that bacteria modified in this way (especially the common gut bacterium $E$. coli, a favourite of the genetic engineers) might present unpredictable dangers because of the new genes they possess, especially if the inserted DNA is not properly characterised or is known to contain potentially dangerous genes. The dangers could apply not only to the human and animal populations; harmless soil or plant bacteria into which genes from plant disease agents have been introduced could possibly pose a threat to crops.

But the advantages, both scientific and practical, which may eventually accrue from these new techniques are so great that there has been enormous pressure for the work to go on. Not

* Report of the Working Party on the Practice of Genetic Manipulation (Cmnd. 6600, HMSO, 50p). only does it make it possible to clone particular genes and thus get to grips with many tricky problems in genetics, but specially engineered bacteria might eventualiy be induced to express the inserted genes and act as custombuilt mini-factories making a valuable product quickly and cheaply.

\section{Code of practice}

The Williams working party was set up in response to recommendations contained in the Ashby Report which, in 1975, first considered the implications of the new genetic engineering techniques. Its brief was to establish a code of practice for conducting these experiments as safely as possible, and to define the role of the central advisory group which Ashby proposed. This, it was envisaged, would be responsible for ensuring that workers intending to perform genetic manipulation experiments were fully conversant with the safe microbiological techniques required.

Addressing the issue of matching particular experiments to the appropriate containment level, the working party has distinguished some 20 separate types of genetic manipulation experiment (see table) which they have then assigned to one of four levels of physical containment.

- Category I: Experiments must be carried out in conditions suitable for containing common human pathogens. (Because the introduction of alien DNA into a bacterium might have unforeseen consequences, the working party recommends that these precautions must be taken even when the source DNA, the vector and the host bacterium are all perfectly harmless in themselves).

- Category II : As I, but in addition the laboratory must be sited away from areas used by the general public and must have controlled air flow and an exhaust-protective cabinet for aerosol-producing operations.

- Category III : As II, but in addition access to the laboratory must be through an airlock only (which should contain washing facilities), all effluent from the laboratory must be decontaminated, and there should be an autoclave inside the laboratory.

- Category IV : Conditions should be equivalent to those already recommended in the Report of the Working Party on the Laboratory Use of Dangerous Pathogens for the most dangerous human and animal pathogens. (There are only a few such laboratories in existence at present, for example those at the Center for Disease Control at Atlanta, Georgia, and at the Microbiological Research Establishment at Porton Down in the UK).

Genetic manipulation experiments can also be made safer using host bacteria and vectors which have been disabled so that they cannot grow outside a particular laboratory environment. Hosts can be crippled by introducing a requirement for some particular growth factor not found in the human or animal body, and disabled vectors which can only infect a special laboratory strain of host can be made.

The working party acknowledges the value of disabled organisms by assigning a lower containment level to experiments in which they are used, and recommends that research to develop new and better disabled strains be encouraged and the strains be made freely available.

Recommendations for implementation The working party's recommendations are also concerned with the machinery needed to ensure that the code of practice is in fact followed. It recommends supervision at two levels, nationally

\section{What is suggested?}

The Williams report recommends that: 1. experiments in genetic manipulation. conducted in appropriate conditions of physical and biological containment, should be encouraged.

2. further work should be done on the development and characterisation of disabled organisms and that any which are developed should be made freely available to all workers in the field.

3. no genetic manipulation experiment should be undertaken in containment conditions less stringent than those used for work with common pathogens.

4. the code of practice (in Appendix II) should be adopted as a basis for the conduct of these experiments.

5. every laboratory conducting these experiments should have a safety committee and a Biological Safety Officer.

6. appropriate training should be made available and be required for all research workers, technicians and biological safety officers in genetic manipulation laboratories.

7. a Genetic Manipulation Advisory Group (GMAG) should be established to advise on appropriate precautions for the conduct of these experiments. 8. the GMAG should be separate from the Dangerous Pathogens Advisory Group (DPAG) although there should be liaison between the two groups. 9. a system of voluntary control should be established as quickly as possible.

10. regulations should be made under the Health and Safety at Work Act to require laboratories to submit experimental protocols to the GMAG. 
through the GMAG and, on the laboratory floor, in the person of a Biological Safety Officer, to be appointed in every laboratory in which genetic manipulation experiments are being carried out.

The Williams working party sees the central advisory group as crucial to the success of any control measures. One of its main functions will be to advise on the category into which a particular experiment should fall and on whether the laboratory is competent to carry it out. To do this the GMAG will need to maintain records of the facilities available in different laboratories; it should in time establish a register of approved laboratories. It should also review experimental protocols regularly and modify the code of practice in the light of new developments in biological and physical containment, and advise on training. The GMAG will be set up in the near future with a secretariat within the MRC, who will be respon- sible to the Secretary of State for Education and Science.

The biological safety officer will be the key person in the enforcement of correct procedures at the individual laboratory level. It will be his job to familiarise himself with the required techniques, and check that experiments are being carried out correctly; he will be responsible for training staff, investigating accidents and maintaining the security of the laboratory.

Recognising the "restraint already shown by the scientific community" since the voluntary moratorium on this work called for by American scientists two years ago, the working party now recommends that certain experiments which they consider do not present a serious hazard (Categories I and II, see table) should go ahead immediately, subject to notification to the GMAG. Experiments which fall into categories III and IV should not proceed until proposals have been

Suggested categorisations for some typical experiments

\begin{tabular}{|c|c|c|c|}
\hline Source of nucleic acid & $\begin{array}{l}\text { Specification } \\
\text { of nucleic } \\
\text { acid sequence }\end{array}$ & Vector/Host System & Category \\
\hline \multirow[t]{4}{*}{ Mammals } & Random & $\begin{array}{l}\text { Phage or plasmid/bacteria, } \\
\text { not disabled }\end{array}$ & IV \\
\hline & Random & $\begin{array}{l}\text { Phage or plasmid/bacteria, } \\
\text { disabled }\end{array}$ & III \\
\hline & Purified* & $\begin{array}{c}\text { Phage or plasmid/bacteria, } \\
\text { not disabled }\end{array}$ & III \\
\hline & Purified* & $\begin{array}{l}\text { Phage or plasmid/bacteria, } \\
\text { disabled }\end{array}$ & II \\
\hline \multirow[t]{4}{*}{ Amphibians and reptiles } & Random & $\begin{array}{c}\text { Phage or plasmid/bacteria, } \\
\text { not disabled }\end{array}$ & III \\
\hline & Random & $\begin{array}{c}\text { Phage or plasmid/bacteria, } \\
\text { disabled }\end{array}$ & II \\
\hline & Purified* & $\begin{array}{c}\text { Phage or plasmid/bacteria, } \\
\text { not disabled }\end{array}$ & II \\
\hline & Purified* & $\begin{array}{c}\text { Phage or plasmid/bacteria, } \\
\text { disabled }\end{array}$ & I \\
\hline \multirow[t]{3}{*}{$\begin{array}{l}\text { Plants and invertebrates } \\
\text { and lower eukaryotes }\end{array}$} & Random & $\begin{array}{c}\text { Phage or plasmid/bacteria, } \\
\text { not disabled }\end{array}$ & II \\
\hline & Random & $\begin{array}{c}\text { Phage or plasmid/bacteria, } \\
\text { disabled }\end{array}$ & I \\
\hline & Purified* & $\begin{array}{c}\text { Phage or plasmid/bacteria, } \\
\text { not disabled }\end{array}$ & I \\
\hline \multirow[t]{2}{*}{$\begin{array}{l}\text { Mammals } \\
\text { Amphibians and reptiles } \\
\text { Birds }\end{array}$} & Random & $\begin{array}{l}\text { Virus capable of infecting } \\
\text { man or growing in tissue } \\
\text { culture cells }\end{array}$ & IV \\
\hline & Purified* & $\begin{array}{l}\text { Virus capable of infecting } \\
\text { man or growing in tissue } \\
\text { culture cells }\end{array}$ & III \\
\hline \multirow[t]{2}{*}{$\begin{array}{l}\text { Viruses pathogenic to } \\
\text { vertebrates }\end{array}$} & Random & $\begin{array}{c}\text { Phage or plasmid/bacteria, } \\
\text { disabled }\end{array}$ & IV \\
\hline & Purified* & $\begin{array}{c}\text { Phage or plasmid/bacteria, } \\
\text { disabled }\end{array}$ & III \\
\hline $\begin{array}{l}\text { Animal viruses, non- } \\
\text { pathogenic to man }\end{array}$ & Random & $\begin{array}{c}\text { Phage or plasmid/bacteria, } \\
\text { disabled }\end{array}$ & II \\
\hline $\begin{array}{l}\text { Bacteria specifying } \\
\text { toxins virulent to man }\end{array}$ & Random & $\begin{array}{c}\text { Phage or plasmid/bacteria, } \\
\text { disabled }\end{array}$ & IV \\
\hline $\begin{array}{l}\text { Plant pathogenic } \\
\text { bacteria }\end{array}$ & Random & $\begin{array}{c}\text { Phage or plasmid/bacteria, } \\
\text { not disabled }\end{array}$ & II \\
\hline Plant viruses & Random & $\begin{array}{c}\text { Phage or plasmid/bacteria, } \\
\text { not disabled }\end{array}$ & II \\
\hline $\begin{array}{l}\text { Bacteria or fungi } \\
\text { non-pathogenic to man, } \\
\text { animals or plants }\end{array}$ & Random & $\begin{array}{c}\text { Phage or plasmid/bacteria, } \\
\text { not disabled }\end{array}$ & I \\
\hline
\end{tabular}

* The term "purified" means fractions with little chance of including any unrecognised extraneous sequences. It is of course possible to have sequences selected because of their pathogenicity and these would raise the level of containment required.

Source: Report of the Working Party on the Practice of Genetic Manipulation (Cmnd. 6600 , H(MSO). approved by the GMAG.

In effect, the working party's technical guidelines are very similar to those published in July by the US National Institutes of Health, though there are important differences between the American and British approach. The US code of practice applies only to work carried out with NIH grants; the UK recommendations will apply to university government and industrial laboratories. The working party has also deliberately avoided the precise assignment of experiments with named organisms to particular categories.

\section{Statutory control}

The Working Party recommends that in the first instance the controls should be voluntarily imposed. But the draft regulations proposed last week by the Health and Safety Commission would provide some measure of statutory control without special legislation having to be passed.

The Health and Safety Commission is a government agency under the aegis of the Department of Employment set up to administer the Health and Safety at Work Act. This Act provides very wide powers to bring in regulations covering any work which might pose a hazard to the health and safety of work people and/or the general public.

The draft regulations, which are now being circulated as a consultative document to interested parties for comment, provide for compulsory notification to the Health and Safety Executive of all experiments which are "intended to alter, or likely to alter, the genetic constitution of any microorganism . . ."As it stands this blanket definition would cover practically all bacterial genetics experiments, and the Executive is asking the scientific community to recommend which conventional types of experiment should be exempted.

In addition the Executive wants to be able to enforce the precautions recommended by the GMAG through the Executive's Inspectors. They can already enforce general measures taken to avoid danger to health, but the Commission is inviting comments from any interested party on the need to include more specific provision for ensuring that the GMAG's advice is taken.

The ultimate sanction for researchers remains the witholding of a grant, however, and the working party recommends that, legal enforcement or no, government departments, research councils and other grant-giving bodies make grants conditional upon investigators following the advice of the GMAG. The working party also hopes that scientific papers will include a statement of both the physical and biological containment procedures used. 